Xiaoxi He

Стручни рад

Hangzhou Public Library,

UDK 027.022:004.4(510)

Hangzhou, China

https://doi.org/10.18485/bibliotekar.2020.62.1.5

alibi_jo@163.com

\title{
INNOVATIVE PRACTICE OF A MODERN PUBLIC LIBRARY - TAKE HANGZHOU PUBLIC LIBRARY AS AN EXAMPLE
}

\begin{abstract}
Established in 1958, the Hangzhou Public Library has developed into a modern library over the past 60 years committed to serving over 9 million residents of the city of Hangzhou. Focusing on the stated goal of "a library for ordinary people and a large study for citizens", the library acts as a pilot among the other libraries in China. This article summarized its three dimensions of work - connecting with libraries overseas, innovating library services in digital time, and the theme branch strategy established in 2008 - and presents activities and programs which support these goals.
\end{abstract}

Keywords: Hangzhou Public Library, international exchange, innovative services, theme branch.

The founding of the Hangzhou Public Library (HPL) was announced on July 1, 1958, in the auditorium of the then Provincial Hangzhou Girls' Middle School. Affiliated at that time to Xinhua Bookstore, the HPL was located in a meeting room on the second floor of the bookstore, and soon it was relocated to Jianren Lane because the ever-growing population of users went beyond its capacity. In 1986, the HPL was relocated again to a dedicated and all-functional building, marking its shift from the traditional book loans to cultural services of a higher level. In October 2008, a modern complex, with a total area of 43, 860 square meters in Jiefang Road, was erected. The new library, right in the Qianjiang CBD of Hangzhou, houses a collection of 5.8 million books and boasts 2,200 seats. It has a full range of facilities including reading rooms, exhibition halls, multipurpose halls, meeting rooms, audio rooms, etc. The year of 2008 stands out as a notable landmark in the HPL's development, not only because the new building enabled it to accommodate more users, with daily visits of 10,000 averagely, but also because since that year the HPL has put forward several 
planned goals - connecting with libraries overseas, innovating library service in digital time, and the theme branch strategy, together with long-term programs that still exist, which has made the HPL of today.

\section{Connecting with Libraries Overseas}

At the end of March 2019, HPL welcomed a guest from the UK, Andrea Ellison, the chief librarian of the Leeds Central Library, whose visit this time was driven by the agreement to be signed between two libraries for the future cooperation. In early September 2019, two librarians from the Milan Public Library (MPL) in Italy, as the third exchange group between two libraries, were sent to Hangzhou for a thirty-day exchange. The first group consisted of two MPL librarians who were sent to the HPL in 2016, and then two HPL librarians were sent to the MPL in 2017.

The HPL's first step to connect with overseas libraries was taken in 2011, when The Image of the West Lake, a program aimed at promoting local and Chinese culture to the world, was launched. The program started with book exchange, by sending the books covering Chinese and Hangzhou themes to overseas libraries with a The Image of the West Lake bookshelf set inside. Upon international sister city program of the Hangzhou Municipal Government and acquaintances HPL has got during international conferences like IFLA WLIC and OCLC, the Stockholm City Public Library in Sweden, the Nekrasov Library in Russia, the Boole Library of the University College Cork in Ireland, the Indianapolis Public Library in the US, and the Gifu City Chuo Library in Japan became the first libraries joining The Image of the West Lake program, which produced subsequent interactions of all kinds such as librarian exchange and multicultural communication events, and at the same time laid a foundation for partnerships to be built with other libraries afterwards.

In the past years, the HPL has built partnerships with 14 libraries in foreign countries and regions, upon which $30 \mathrm{HPL}$ librarians visited Germany, Ireland, Russia, Sweden, the USA, Japan, and other countries, and the HPL received more than 20 exchange librarians from all over the world. Besides, by taking advantage of the existing relationships, some cooperative events were held to introduce the culture to each other through exhibitions, reading activities, and online interactions.

Partnerships built with overseas libraries have produced something unexpected, namely, a worldwide network, the power of which was being recognized through an exhibition in 2016, the year China hosted the G20 Summit 
in Hangzhou. Considering the city would receive full attention from all around the world at that time, the HPL intended to launch an Ordinary Hangzhou exhibition program for city promotion. After the idea was proposed, a total of 11 partner libraries responded to participate in the program and finally, 55 photos taken by Hangzhou citizens and a ten-minute documentary about Hangzhou were exhibited in these libraries during G20 Summit.

Due to connections with libraries around the world, the HPL keeps itself updated timely with information in the library field, and at the same time builds a path to "go out" and "bring in"1 functioning as a bridge between Hangzhou and the outside world.

\section{Innovating Library Services in Digital Time}

With one of China's largest internet company Alibaba based in Hangzhou, public services in the city are transformed in forms and contents. By realizing the importance to innovate services to better meet the real-time demand of the public, the HPL actively cooperates with internet companies and realizes traditional programs in new ways.

\section{The Alipay Sesame Credit-Based Library Service}

On July 17, 2012, the State Council of the People's Republic of China approved the agreement to adjust the member units and main responsibilities of the interministerial joint conference for the construction of a social credit system. ${ }^{2}$ In 2014, the Planning Outline for the Construction of Social Credit System (2014-2020) was issued and on July 18, 2017, guided by the National Development and Reform Commission, the Summit on Credit City Development in China hosted by the Xinhua News Agency and the Hangzhou Municipal Government was opened. ${ }^{3}$

L. Rui, "Zouchuqu qingjinlai-hangzhou tushuguan guoji jiaoliu xiangmu de shijian yu tansuo" ("Go out and Bring in: Practice and Exploration of the International Exchange Project of Hangzhou Library”), Tushuguan yanjiu yu gongzuo (Library Science Research and Work), vol. 173, 11 (2018): 7-11, DOI: CNKI:SUN:TSGY.0.2018-11-002.

2 Yuandiancredit (ed.), Shehui xinyong ti'xi jianshe zhi "dili fenjin de wunian" (The inspiring five years of the construction of social credit system), https://www.creditchina.gov.cn/xinyongyanjiu/ xinyongyanjiuhuicui/201712/t20171201_98144. html (accessed 7. 4. 2018).

3 Guotu yanjiuyuan (Research Institution of National Library of China) (ed.), "Shanghai tushuguan fachu guonei shouzhang xinyongjiehsuka" ("The first credit reader card was issued by Shanghai Library"), Guojia tushuguan xuekan (Journey of the National Library of China) vol. 28, 6 (2014): 113. 
In 2014, the Alipay Sesame Credit was introduced to public library communities for the first time $e^{4}$, putting forward a concept of credit-based library service which is provided with reference to users' credit scores given by a third party. Since April 23, 2017, the HPL has started to combine public library service with the Alipay Sesame Credit. Based on an advanced information technology system, the credit service includes cancelling registration fee by credit score, borrowing and reading books online, listening to audiobooks via a personal internet platform, and door-to-door book-delivery, which means that the HPL users can enjoy these services by only installing the Alipay application on their mobile phones. On September 2, 2017, this service has enlarged the user group by dropping the access credit score to 550, which is the setting start score of Sesame Credit. The number of newly registered users supported by the new policy is almost 30,000. The annual online borrowing reaches up to 7,000 transactions. ${ }^{5}$

Taking advantage of the internet personal credit platform, the credit service has not only saved the cost of the self-built system but also innovated the service to inspire users' good reading behaviors, and to contribute to the construction of social credit system.

\section{Happy to Read Program}

Happy to Read program started three years ago. In February 2016, a coverage titled by What! Books in the Bookstore Can Be Taken Back Home Free of Charge attracted people's attention [5], which could be considered as the first appearance of the Happy to Read program in the public. With an application installed on mobile phones, the program enables the HPL users to take books back home free of charge by only swiping their mobile phones in partner bookstores. Besides, the application also supports exchanging books among HPL users by swiping mobile phones without going to the library.

Happy to Read program sets several rules: (1) reference books, textbooks, journals, magazines are not in the list of the program; (2) the annual quota for each user is no more than 36 books; (3) the book can only be chosen when its duplicates are under the limit in the HPL; (4) the price of each chosen book is

4 W. Zhang, "Hulianwang+' shidai xia gonggong tushuguan yuedu tuiguang fuwu tantao" ("Discussion on reading promotion services of public libraries in Internet plus era: take Hangzhou Public Library as an example"), Tushuguan yanjiu yu gongzuo (Library Science Research and Work) vol. 39, 1 (2018): 65-68.

5 X. Shen, "Nani! Hangzhou xinhua shudian de xinshu keyi mianfei jiehuijia kan" ("What! Books in Bookstore can be Taken Back Home Free of Charge"), http://shanghai.xinmin.cn/ msrx/2016/02/04/29461968.html (accessed 20. 8. 2019). 
no more than 150 RMB; (5) chosen books must be finally returned to the HPL. Based on modern technologies and social resources, Happy to Read program increases people's interest to read and, more importantly, it transforms library users from passive recipients to the ones involved in the collection development of the HPL. The program has already had five partner bookstores all over the city and has served 46 thousand users with 370 thousand transactions.

\section{Online Book Club}

Online Book Club aims to provide a platform for peers in different countries to meet, talk, and share. It takes advantage of connected libraries worldwide to find youth in their city and produces a meeting together for one specific text discussion. The main purpose of the program is to help young people today understand people from different cultures and countries better.

There are six simple steps to organize a meeting, most of which are operated online:

STEP 1: Two libraries search for participating groups in their cities;

STEP 2: Two groups decide the exact time to meet online;

STEP 3: Two libraries together decide on a text (poems, one paragraph in a book, lyrics) for discussion and send it to groups two weeks in advance;

STEP 4: Groups prepare an introduction (to simply introduce their homeland, city, and culture), as well as the study of the text;

STEP 5: Online meeting.

In March 2019, the first activity of the program was successfully held in the cyber world connecting students from Zhejiang International Studies and students from Tallin Lilleküla Gymnasium based on months of communications between the Tallinn Central Library and the HPL. The chosen text was a piece of poetry The White World by Chinese poet Jidi Majia which is available both in Chinese and Estonian. The second activity is being planned by the HPL and the Gifu City Chuo Library in Japan with a chosen novel by Japanese writer Naoki Matayoshi.

\section{Theme Branch Strategy}

On May 5, 2019, the Piano Branch of the HPL was officially opened in the northern part of the city. Located inside the Langlang Art World, the studio of the Chinese concert pianist Lang Lang who has performed with leading 
orchestras in the USA, Canada, and Europe, the Piano Branch has a collection of over 2,000 books, primarily consisting of piano teaching materials, music scores, and biographies of musicians. This Branch is built in a typical way the HPL develops its branches, with venue provided and operation expenses covered by cooperative organizations and institutions, such as Langlang Art World in this case, and collection, staff, and library service provided by the HPL.

Since 2008, based on the progress the HPL has made in the creation of public library service system around the city, it has taken an evolutionary path in building its branch libraries by themes, to better satisfy diversified and specialized needs of the public, and further enrich the content and mode of the public library service system, with the support of the city government and social resources. Up to now, there are 20 theme branches scattered all around Hangzhou - the City Life Branch, the Music Branch, the Film Branch, the Buddhism Branch, the Sports Branch, the Science and Technology Branch, the Environment Branch, the Tea Culture Branch, etc.

Slightly different from the purpose of general libraries, namely, to provide services meeting the common needs, the theme branches are built to meet different demands in a fast-changing society in the first place, and then to make professional subdivided information and knowledge reach more general audience. $^{6}$

Various kinds of library services and programs are carried out, all of which in the best way cover specific themes. For example, through the Hangzhou Citizens Choir Institution program in the Music Branch, by regularly recruiting students from the general audience and giving training sessions twice a week in the past nine years, two strong choirs have been formed. In 2013, its adult choir won the Gold Award in Zoltan Kodaly International Choir Festival in Budapest and, its children choir won the Gold Award in World Youth \& Children's Choir Festival in Hong Kong in 2019; the Environment Branch, established in cooperation with the Hangzhou Environment Group in 2016, organizes recycling events in waste transfer stations around the city throughout the year and gradually has developed into a base for environmental education to serve local schools and families; the Buddhism Branch, located in temple area of Hangzhou, has a collection of 10,000 books including Buddhist scripture, Buddhist academic works, Buddhist art,

\footnotetext{
J. Zhu, "Gonggong tushuguan tese fuwu de shijian yu tantao" ("Practice of and Discussion on the Development of Characteristic Service in Public Libraries: Taking the Hangzhou Public Library's Sports Branch as an Example"), Tushuguan zazhi (Library Journal) vol. 38, 4 (2019): 56-60, DOI: 10.13663/j.cnki.lj.2019.04.011.
} 
etc. It holds Buddhism related salons, lectures, and exhibitions regularly and builds a platform for people who are interested in Buddhist culture and those who study the history of Hangzhou in which the role of Buddhist culture cannot be neglected.

\section{References}

1. Guotu yanjiuyuan (Research Institution of National Library of China), ed. „Shanghai tushuguan fachu guonei shouzhang xinyongjiehsuka” („The first credit reader card was issued by Shanghai Library"). Guojia tushuguan xuekan (Journey of the National Library of China) vol. 28, 6 (2014): 113.

2. Rui, L. „Zouchuqu qingjinlai-hangzhou tushuguan guoji jiaoliu xiangmu de shijian yu tansuo” („Go out and Bring in: Practice and Exploration of the International Exchange Project of Hangzhou Library"). Tushuguan yanjiu yu gongzuo (Library Science Research and Work) vol. 173, 11 (2018): 7-11. DOI: CNKI:SUN:TSGY.0.2018-11-002.

3. Shen, X. Nani! Hangzhou xinhua shudian de xinshu keyi mianfei jiehuijia kan (What! Books in Bookstore can be Taken Back Home Free of Charge), 2016. http:// shanghai.xinmin.cn/msrx/2016/02/04/29461968.html (accessed 20. 8. 2019).

4. Yuandiancredit, ed. Shehui xinyong tixi jianshe zhi "dili fenjin de wunian" (The inspiring five years of the construction of „social credit system”), 2017. https://www. creditchina.gov.cn/xinyongyanjiu/xinyongyanjiuhuicui/201712/t20171201_98144. html (accessed 7. 4. 2018).

5. Zhang, W. „Hulianwang+ shidai xia gonggong tushuguan yuedu tuiguang fuwu tantao” („Discussion on reading promotion services of public libraries in Internet plus era: take Hangzhou Public Library as an example"). Tushuguan yanjiu yu gongzuo (Library Science Research and Work) vol. 39, 1 (2018): 65-68.

6. Zhu, J. „Gonggong tushuguan tese fuwu de shijian yu tantao” („Practice of and Discussion on the Development of Characteristic Service in Public Libraries: Taking the Hangzhou Public Library's Sports Branch as an Example"). Tushuguan zazhi (Library Journal) vol. 38, 4 (2019): 56-60. DOI: 10.13663/j.cnki.lj.2019.04.011. 


\section{Сијаоси Хе}

Јавна библиотека у Хангџоу, Кина

alibi_jo@163.com

\section{ИНОВАТИВНА ПРАКСА ЈЕДНЕ МОДЕРНЕ ЈАВНЕ БИБЛИОТЕКЕ - ПРИМЕР ЈАВНЕ БИБЛИОТЕКЕ ГРАДА ХАНГЏОА}

Сажетак: Основана 1958. године, Јавна библиотека у Хангџоу се током последњих 60 година развила у модерну библиотеку која је на услузи становницима деветомилионског града Хангџоа. Фокусирајући се на постављени циљ „библиотека за обичне људе и велика радна соба за све грађане”, ова библиотека представља узор другим библиотекама у Кини. Чланак сажето представља три димензије рада повезивање са библиотекама у иностранству, иновирање библиотечких услуга у дигиталном добу, и стратегију развоја тематских огранака која је утврђена 2008. године, као и активности и програме који подржавају постизање задатих циљева.

Кључне речи: Јавна библиотека у Хангџоу, међународна размена, иновативне услуге, тематски огранак.

Примљено: 4. септембра 2019.

Исправке: 30. септембра 2019.

Прихваћено: 7. новембра 2019. 